\title{
Chris Mathieu \& Jesper Strandgaard Pedersen (Eds.): Dansk film i krydsfeltet mellem samarbejde og konkurrence. Lund: Ariadne Förlag. 2009.
}

\section{Jakob Isak Nielsen}

MedieKultur 2010, 49, 182-186

Published by SMID | Society of Media researchers In Denmark | www.smid.dk The online version of this text can be found open access at www.mediekultur.dk

Dansk film i krydsfeltet mellem samarbejde og konkurrence tager en række vigtige emner op angående udviklingen af dansk film fra midten af halvfemserne til ca. 2007 - herunder økonomiske, juridiske, organisatoriske, institutionelle og produktionsanalytiske problemstillinger, som har stået i skyggen af mere æstetisk og fortællemæssigt orienterede studier af fx dogmefilmene og Lars von Trier. Grundet udgivelsens begrænsede omfang vil nærværende anmeldelse ikke kun knytte kommentarer til overordnede forhold ved bogen, men også til hvert enkelt bidrag.

Bogens syv kapitler præsenteres som en viderebearbejdning af en række forskningsresultater, som blev præsenteret på en konference på CBS i 2006 med titlen "Venner for livet - dansk film i krydsfeltet mellem samarbejde og konkurrence". 'Venner for livet' kunne man næppe have kaldt udgivelsen, men Dansk film i krydsfeltet mellem samarbejde og konkurrence er til gengæld en lidt omstændelig titel. Titlen kunne have gavn af mere "halløj og pip", som Ole Olsen ønskede sig af Nordisk Films første fiktionsfilm (p. 95).

Sådanne 'kompilationer' rummer altid en fare for, at bidragydernes varierende erkendelsesinteresse, skrivefacon og teoretiske ståsted truer udgivelsens sammenhængskraft. Redaktørerne er sluppet hæderligt fra harmoniseringsprocessen, men der er undertiden lovligt store udsving i abstraktionsniveau og sproglig fremstilling - fra uprætentiøs prosa om "pæn stigning" (p. 19) i billetsalg og en industri, der står "rimeligt stærkt" (p. 33), til unødigt mystificerende passager om "den heteronome del af det kulturelle produktionsfelt" (p. 62). Der er også eksempler på analyser, der decideret modsiger hinanden. I Philipsens artikel om spil- 
leregler i filmskabelse kan man fx læse, at "rammesætning kan være med til at skabe innovative og forskelligartede film i stedet for ensartede film" (p. 168), mens der i Malou Strandvad og Mathieus artikel står, at dansk film følger en produktionsmodel, som gør, at vi ikke "kan forvente at finde stor diversitet" (p. 55). Problemet er ikke, at der er modstridende analyser, men at det ikke bliver annonceret eller kommenteret - enten i forordet, i de enkelte artikler eller $i$ en sammenfatning.

Hvad angår de enkelte bidrag, får man det bedste overblik ved at tage udgangspunkt i de tre emnefelter, som bogen er delt op i: "Analytiske blik på den danske filmbranche" (pp. 15-89), "Kreative filmmiljøer" (pp. 91-141) og "Kreative metoder og regler" (pp. 143-196). Første del består af Strandgaard Pedersen og Mathieus "Udviklingstræk i dansk film 19952007", Strandvad og Mathieus "Den danske model - hvad består den af?" og Fugl Eskjærs "DFI og dansk filmstøtte - en analyse af forandringer og konflikter i dansk film".

Strandgaard Pedersen og Mathieus artikel ønsker at vurdere "tingenes tilstand" (p. 16) og tage stilling til "i hvilket omfang og på hvilke områder, det i givet fald giver mening at tale om krise i dansk film" (ibid.). Artiklen sammenbringer en række statistiske oplysninger om dansk film (produktionstal, solgte biografbilletter ift. udenlandske film mv.). Det er en udmærket oversigtsartikel, hvor de væsentligste parametre er taget med. De to væsentligste indvendinger imod artiklen er, at debatten om 'krise' i dansk film ikke kun er pisket op på baggrund af en økonomisk diagnose, men på baggrund af udsagn om fortællemæssig, genremæssig og æstetisk krise. Disse 'kriseparametre' kan ikke belyses fyldestgørende ud fra artiklens statistiske undersøgelser. Det kan man imidlertid ikke se af den formulerede erkendelsesinteresse, som både er bred og dyb: "Afslutningsvis giver vi en vurdering af væsentlige udviklingstræk i dansk film samt en vurdering af dansk films nuværende situation" (p. 16). Her ville det være klædeligt med et forbehold og en skarpere afgrænsning af, hvad artiklen rent faktisk kan påvise.

Den anden indvending går på, at virkeligheden har overhalet bogen indenom. Opgørelsen slutter i 2007, hvilket kan undre, eftersom man andetsteds i bogen (p. 145) kan finde biograftallene for rekordåret 2008, hvor der blev solgt over 4,3 mio. billetter til danske film. Den største udfordring ift. artiklens overordnede konklusion er imidlertid biograftallene for 2009, hvor der kun er solgt godt 2,4 mio. billetter til danske film (dfidk) samtidig med, at biografsalget generelt steg til rekordhøje 14,1 mio. (dst.dk). At man "skal lede godt efter tegn på krise" (p. 33) er således knap så entydigt, da salget af billetter til danske film faldt med $43 \%$ og andelen af biografbilletter solgt til danske film er nede på 17 \% (dst.dk). Samtidig sætter 2009 spørgsmål ved parametrene for at måle succes. Stieg Larsson-filmatiseringerne tæller ikke som danske produktioner, men mon ikke koproducent Nordisk Film, som har de skandinaviske biograf- og dvd-distributionsrettigheder, er godt tilfreds med året alligevel. 2009 var også et usædvanligt år, idet årets største danske billetsluger, Sorte kugler (Anders Matthesen), ikke fik produktionsstøtte af det ellers så centrale DFI (Det Danske Filminstitut). Alt dette kunne forfatterne med god grund ikke vide i marts 2009, men spørgsmålet 
er, om denne type af information ikke egner sig bedst til at blive præsenteret på nettet, hvor man jo også selv har kunnet finde statistikkerne.

Malou Strandvad og Mathieu forsøger i deres kapitel at etablere en dansk model for filmproduktion. Det anføres, at modellen er "baseret på en empirisk iagttagelse af de handlingsmønstre og ideer, som cirkulerer i det danske filmfelt" (p. 38), men vi hører ikke yderligere om, hvordan dette metodisk er grebet an. Artiklen opstiller tre modeller for filmproduktion: high concept, auteur og high framework, hvor den sidste skal være karakteristisk for dansk filmproduktion. Artiklen tager afsæt i en opfattelse af modeller som "klare, koncise abstraktioner" (p. 41) og - med Max Weber - som "et tankebillede, altså et billede vi tænker os til, og som vi kan bruge til at tænke med" (ibid.). Det er således et metodisk valg, at de tre modeller ikke gengiver alle nuancer, men kapper en hæl og hugger en tå. Det er modellernes største styrke, da de stilles skarpere op som idealtyper ud fra velvalgte parametre som styrende logik, legitimering, privilegeret aktør mv. (p. 48). Imidlertid svækker det naturligvis forklaringskraften i forhold til de faktiske forhold i filmbranchen, og her sker der desværre en glidning i artiklen, hvor tankebilledet kommer til fremstå som værende lig den faktiske danske model for filmproduktion. Mod slutningen af artiklen bliver produktionsmodellen ubemærket til "high framework systemet" (pp. 55-57), som afslutningsvis bliver til "det danske system" (p. 57). Det ville i den sammenhæng have været fordelagtigt at skelne mere klart mellem produktionsmodel, 'regimet' og produktionssystem.

Fugl Eskjærs artikel er et af bogens stærkeste bidrag. Han analyserer den danske filmstøtte med særlig vægt på, hvordan Filmloven fra 1997 ændrede DFl's "struktur og funktion". Artiklen undersøger de "systemiske relationer og konflikter, som kendetegner dansk film" (p. 61). Mens det var mindre entydigt, hvad der hos Malou Strandvad og Mathieu lå i ordet 'system', så skal det her forstås i forlængelse af Luhmanns systemteori. Dette perspektiv er usædvanligt velegnet til at afdække filmlovens og DFl's navigation i konfliktfyldte vande. Metodisk giver det god mening at koble dette perspektiv med diskursanalysen, selvom artiklens faktiske analyser af diskurser ikke er dybere, end at man kunne forestille sig artiklen skrevet uden dennes mellemkomst.

Bogens anden del, "Kreative filmmiljøer", består af Isak Thorsens artikel om Nordisk Film ("Filmfabrikken i Valby") samt Strandgaard Pedersen, Boutaiba og Reff Pedersens "Zentropa - identitetsskabelse via medierne". Thorsen beskriver Nordisk Film fra grundlæggelsen og frem med øje for, hvorledes selskabets økonomiske succes blev skabt via dets "højt specialiserede og rationelle organisering af filmproduktionen" (p. 93). Bidraget er et stykke veldokumenteret virksomhedshistorie med direkte referencer til Nordisk Film Samlingen og en række udtalelser fra centrale aktører. Isoleret set er det en god og gedigen artikel, men til gengæld en 'fremmed fugl' i forhold til de øvrige artikler, som alle fokuserer på forhold fra ca. 1995 og frem. Artiklen er i tråd med Thorsens ph.d.-projekt, og dens inkludering vidner om, at bidragene er sammensat efter 'de forhåndenværende søms princip' snarere end strategisk udvalgt for at understøtte en skarpt defineret problemstilling. En artikel om Nordisk 
Film - eller andre aktører i den danske filmbranche - fra midten af 90'erne og frem ville give udgivelsen en skarpere profil.

Strandgaard Pedersen, Boutaiba og Reff Pedersens artikel runder denne sektion om 'kreative filmmiljøer' af. Den fokuserer på identitetsskabelse via Zentropas strategiske kommunikation. Den rummer indledningsvis nogle skrubtudser såsom vendingen "narrative genrer", der inden for medietekstanalysen er utilgivelig begrebsforvirring, men er i øvrigt en interessant artikel med en omfattende mængde research i ryggen. Særligt inddragelsen af journalistinterviews drages der nytte af, og en typologi over Zentropas reaktionsmønster over for journalister er glimrende fremanalyseret og formidlet (pp. 128-34). Ligesom Strandgaard Pedersen og Mathieus indledende artikel har virkeligheden imidlertid overhalet bogen indenom, da artiklen åbenbart er skrevet forud for Nordisk Films opkøb af halvdelen af anparterne i Zentropa Folket ApS i februar 2008. Dette forhold rokker ved en række positioner og udlægninger i artiklen, som altså allerede trænger til at blive opdateret - særligt da artiklen heller ikke tager højde for Susanne Biers rolle og funktion i foretagendet - fx i forhold til virksomhedens "Rasmus Modsat"-image.

Bogens sidste sektion, "Kreative metoder og regler", indledes af Heidi Philipsens inspirerende artikel om spilleregler og kreative arbejdsprocesser. Givet dets betydning i artiklen, kunne man efterlyse en mere præcis og udførlig definition af begrebet 'stilladsering' (p. 146), men generelt er artiklen godt opbygget rent metodisk ift. inddragelsen af didaktiske, psykologiske og spilteoretiske positioner. Sangen om spillereglers betydning ifm. Filmskolens penneprøver, dogmefilm, Triers film mv. har vi ganske vist hørt før fra såvel filmskaberne selv som fra diverse bøger og artikler (fx Raskin, 2000; Christensen, 2004; Jørgensen, 2003), men artiklen bevæger sig i retning af et essentielt forhold, som ikke er tilstrækkeligt belyst: spillereglernes karakter. Ikke kunstens regler, men reglernes kunst, om man vil - forstået på den måde, at selve regelformuleringen og regeliscenescettelsen kommer i fokus. Ikke at måtte benytte underlægningsmusik eller kun at måtte benytte supertotaler handler i begge tilfælde om stilistisk iscenesættelse, men har forskelligt anvendelses- og læringspotentiale foruden forskelligartede æstetiske konsekvenser i den endelige film.

At der her er tale om en gryende forskningsinteresse afspejles ved, at artiklen ikke har afklaret en række problemstillinger inden for feltet. Fx angives det i forlængelse af diskussionen om De fem benspand: "Endvidere bør stilladsering være individuelt tilpasset (som det er tilfældet for Leth)" (p. 167). Det rejser imidlertid tvivl om de spilleregler, der ifølge Philipsen selv har haft stor indvirkning på dansk film: Hverken dogmereglerne (og næppe heller Filmskolens penneprøver) er formuleret i forhold til en enkelt filmskabers særlige sensibilitet. Uden at kende til samtlige Filmskolens penneprøver forekommer det mig, at de typisk er formuleret i forhold til fortællemæssige problemstillinger af en mere generel karakter, mens dogmereglerne er formuleret i forhold til filmhistoriske traditioner og konventioner særligt poleret mainstream og den franske nybølge. Dette problem adresseres ikke direkte her. I afsøgningen af spillereglers virkefelt og forklaringskraft skal man ikke kun orientere sig mod de individer, grupper og institutioner, der formulerer, rammesætter eller imødekom- 
mer spillereglerne, men også den baggrund de er formuleret på. Spillereglernes (udviklings) potentiale kan ikke isoleres fra deres underliggende dagsorden: er den fx af stilistisk, fortællemæssig, genremæssig og/eller ideologisk art? Her ligger nogle muligheder for at nuancere lærings- og udviklingsforskellene knyttet til de fremførte spilleregler i dogmefilmene, penneprøverne og De fem benspand.

Bogens afsluttende kapitel og sidste del af afsnittet om kreative metoder og regler er Per Darmers "Dogme OA - dogmereglerne som model for organisationsanalyse". Fra et film- og medievidenskabeligt perspektiv - og i forhold til bogens titel - er der tale om et antiklimaks. Kapitlet handler groft sagt ikke om dansk film. Der er tale om teoriudvikling inden for organisationsanalytisk metode med inspiration fra dogmereglerne og dogumentaryreglerne. At reglerne stammer fra filmens verden er reelt set underordnet. Trods betegnelsen 'analyse' i kapitlets titel rummer den ikke analyser af - eller empiriske koblinger til - en specifik organisation, som burde være basis for al god teoriudvikling.

Det anbefalelsesværdige ved bogen er styrken af enkelte artikler snarere end en samlet afdækning af én overordnet problemstilling. Og så er vi tilbage ved bogens titel igen. For det største problem med titlen er faktisk, at den giver et skævt indtryk af de problemstillinger, som adskillige af bogens bidrag tager op. Strandgaard Pedersen og Mathieus artikel kommer ganske vist ind på dansk films konkurrence med udenlandske film, men handler mere om udviklingstræk - og i øvrigt ikke om samarbejde. Philipsens kapitel kommer nok ind på samarbejde inden for små produktionsteams, men det handler egentlig ikke om konkurrence mv. Givet artiklernes varierende teoretiske ståsted og interessefelt er det forståeligt, at bogen ikke har fået en rammende titel - kunne den overhovedet det? Muligvis ikke, men et sammenfattende kapitel kunne fx have kommenteret behovet for at opdatere artiklerne om udviklingstræk i dansk film fra 1995 til 2007 og Zentropas identitetsskabelse og kommunikationsstrategi frem til (formodentlig) 2006 (p. 117), ligesom det kunne have fremhævet koblinger mellem bidragene og dermed forbedret udgivelsens sammenhængskraft.

Jakob Isak Nielsen

Adjunkt

Institut for Informations- og Medievidenskab

Aarhus Universitet

jakobisak@hum.au.dk

\section{Referencer}

Raskin, R. (2000) (Ed.). P.o.v., 10 - et særnummer om dogmefilmene. Århus: Institut for Informations- og Medievidenskab.

Christensen, O. (2004) (Ed.). Nøgne billeder - de danske dogmefilm. Holte: Medusa.

Jørgensen, H. (2003). "Begrænsningens kunst på Den Danske Filmskole". In 16:9, 1(4). www.16-9.dk/200311/side06_filmskolen.htm 